\title{
PRICE DETERMINANTS OF BRED COWS
}

\author{
JAMES L. MITCHELL* \\ Department of Agricultural Economics, Kansas State University, Manhattan, Kansas
}

DERRELL S. PEEL

Department of Agricultural Economics, Oklahoma State University, Stillwater, Oklahoma

\section{B. WADE BRORSEN}

Department of Agricultural Economics, Oklahoma State University, Stillwater, Oklahoma

\begin{abstract}
Hedonic modeling of Oklahoma cow auction data is used to determine the market value of bred cow characteristics. We use Agricultural Marketing Service data that let us consider more years and more lots of cattle than is typical for a cattle hedonic study. The greatest price premiums were for black, late-gestating cows, categorized as high quality by market reporters and weighing between 1,600 and 1,700 lb. Previous research on optimal cow size finds much smaller-size cows are optimal, and our research finds that larger cows receive a lower price per pound but still receive a substantially higher price per head.
\end{abstract}

Keywords. Aggregated data, bred cows, hedonic models, livestock marketing

JEL Classifications. C43, D44, Q13

\section{Introduction}

Bred cows are inputs into beef production. They are a joint product because of the future flow of calves (including the unborn calf) being bundled with the slaughter value of the cow at the time of sale. Often producers market replacement cows and heifers as bred. Additionally, many producers sell older cull cows as bred cows. Research has determined that cull cow retention and marketing as bred can be economically viable (Amadou, 2012). Although past studies have identified several cow-marketing strategies (Amadou et al., 2014; Lawrence, 2002; Trapp, 1986), none have considered the contribution of bred cow traits to total value. A standard methodology to quantify product differentiation and price variability is the hedonic approach.

Helpful suggestions by Brian Adam and Kellie Raper on an earlier draft are gratefully acknowledged. We are thankful for data collection assistance provided by the Oklahoma City U.S. Department of Agriculture (USDA), Agricultural Marketing Service staff. Mitchell and Peel received support from the Breedlove Professorship of Agribusiness. Brorsen received funding from the Oklahoma Agricultural Experiment Station and USDA National Institute of Food and Agriculture, Hatch Project number OKL02939.

*Corresponding author's e-mail: jlmitch19@ksu.edu 
Numerous studies have used hedonic models to explain price variation among agricultural products. In particular, considerable research effort has sought to identify factors affecting feeder cattle price differentials (e.g., Avent, Ward, and Lalman, 2004; Bailey, Peterson, and Brorsen, 1991; Buccola, 1980; Coatney, Menkhaus, and Schmitz, 1996; Faminow and Gum, 1986; Marsh, 1985; Schroeder et al., 1988; Schulz, Dhuyvetter, and Doran, 2015; Williams et al., 2012; Zimmerman et al., 2012). Early studies focused on the value of feeder cattle physical characteristics. Later studies incorporated regional and temporal factors and have assessed the value of various value-added programs and sales (Blank, Saitone, and Sexton, 2016; Mallory et al., 2016). Results from these academic studies have provided producers with valuable information on the linkage between feeder cattle characteristics and their accompanying premiums and discounts.

In addition to feeder cattle hedonic analyses, research has also determined factors affecting purebred bulls (Dhuyvetter et al., 1996; Vestal et al., 2013), cowcalf pairs (Parcell, Schroeder, and Hiner, 1995), and cull cow prices (Mintert et al., 1990). Both studies of cows, as well as Peel and Doye (2008), note significant premiums for cows that are bred, but the studies did not focus on the hedonic prices for bred cows alone. Bred cows are the only class of cattle that have not been explicitly studied in a hedonic framework.

This study addresses the question of how physical characteristics and temporal and market factors influence the price of bred cows sold in seven auctions across the state of Oklahoma. Research on bred cow price determinants provides sellers with information on which traits buyers find desirable along with the value of those attributes. Furthermore, buyers will be able to make a more efficient decision about whether to purchase or raise replacements (Schulz and Gunn, 2014). Thus, information about the value placed on individual bred cow traits is potentially useful to many in the cattle industry.

\section{Agricultural Marketing Service (AMS) Data}

The most common unit of observation in hedonic livestock research is auction lots. Typically, researchers enlist the services of staff, research associates, and trained personnel to record results from livestock auctions, which allows collection of a wide range of animal characteristics (e.g., Avent, Ward, and Lalman, 2004; Bailey, Peterson, and Brorsen, 1991; Schroeder et al., 1988). Data for this research are from aggregated U.S. Department of Agriculture (USDA)AMS bred cow reports, where aggregation occurs across varied categories of lots. Given that the data of this research are aggregate, a brief discussion of data aggregation is warranted.

The literature on aggregated data has two main thrusts. The objective of the first deals with the aggregation problem, whereas the second is concerned with prediction. Considerable effort has been devoted toward the aggregation 
problem-namely, the problem of aggregation bias defined as the deviation of macroparameters from the average of the corresponding microparameters (Gupta, 1971; Lee, Pesaran, and Pierse, 1990; Sasaki, 1978; Thiel, 1954). The central focus of the prediction problem is in determining whether to use microor macromodels to predict an aggregate dependent variable (Grunfeld and Griliches, 1960; Pesaran, Pierse, and Kumar, 1989). Both problems, prediction and aggregation bias, have been addressed in numerous empirical studies.

Studies in various fields of economic research have documented the implications from using aggregated data sets. Richter and Brorsen (2006) derive a theoretical model that shows that aggregate data create heteroskedasticity but do not create bias if the underlying model is linear. Shumway and Davis (2001) show that errors in inference, stemming from aggregation, are small relative to errors attributable to incorrect choice of functional form or failure to account for time series components of the data (Shumway and Davis, 2001).

Given that the data in this research are aggregated, it is important to note that although bias may be present, the bias is likely minimal because the bred cow categories are relatively narrow and relationships are approximately linear. Another point of discussion is interval-censored data. Although methods exist that could be applied to the data in this research, the methods for interval-censored data would not work well because the intervals of this data are highly irregular.

Although there are many challenges associated with aggregate data sets, the studies reviewed here suggest that a lot can be learned from aggregated data. To date, no studies have made use of aggregate data, where aggregation occurs across lots, to determine the market value of livestock characteristics. This research makes use of an aggregate data set that reports prices from seven livestock auctions.

In Oklahoma, $\mathrm{AMS}^{1}$ summarizes transactions from seven livestock auctions. The Oklahoma City AMS office granted access to their archive system, which provided all of the relevant historical auction reports. ${ }^{2}$ The AMS auction reports include the following data: date, price, age, weight, months bred, quality, hide color, location, and sale volume. With the assistance of the Livestock Marketing Information Center (LMIC), an automated program was developed to process the text files, totaling close to 6,000 individual files. Observations with missing values and characteristics are dropped from the data set. In total, 135 observations were dropped because of inconsistencies. The final data set includes 776 weeks composed of 14,811 bred cow lots from January 5, 2000, to May 21, 2015 . The price of a bred cow lot ranges from $\$ 330 /$ head to $\$ 3,400 /$ head. Weight

1 Data are from AMS market reports: KO LS753, KO LS157, KO LS752, KO LS151, KO LS757, KO LS760, and KOLS152.

2 Only the five most recent years of auction reports are publicly available through the AMS portal system. 
Table 1. Descriptive Statistics of Selected Bred Cow Characteristics for Seven Oklahoma Auctions, January 2000-May 2015

\begin{tabular}{|c|c|c|c|c|}
\hline Variable & Mean & $\begin{array}{l}\text { Standard } \\
\text { Deviation }\end{array}$ & Minimum & Maximum \\
\hline Price (\$/head) & 936.7 & 390.4 & 330.0 & $3,400.0$ \\
\hline Age $(\text { years })^{\mathrm{a}}$ & 5.6 & 2.4 & 1.0 & 10.0 \\
\hline Weight (lb.) & $1,126.4$ & 118.9 & 700.0 & $1,700.0$ \\
\hline Months bred & 5.4 & 1.4 & 1.0 & 9.0 \\
\hline $\begin{array}{l}\text { Replacement cow volume } \\
\text { (number of head sold })^{\mathrm{b}, \mathrm{c}}\end{array}$ & 267.3 & 234.6 & 8.8 & $2,343.0$ \\
\hline Cow quality ${ }^{\mathrm{d}}$ & 3.4 & 0.9 & 1.0 & 5.0 \\
\hline
\end{tabular}

${ }^{a}$ Heifers are coded as 1-year-olds for convenience.

${ }^{b}$ Replacement cow volume is the total number of bred cows and cow-calf pairs sold.

${ }^{c}$ U.S. Department of Agriculture market reports list the total number of cows and bulls sold, as well as the percentage of head that are slaughter cows and bulls. Multiplying the percentage of slaughter animals sold and the total number of head sold gives the total number of slaughter animals. Replacement cow volume is obtained by subtracting the number of slaughter animals sold from the total number of head sold at auction.

${ }^{\mathrm{d}}$ Cow quality is coded as low $=1$, low-average $=2$, average $=3$, average-high $=4$, and high $=5$.

Note: Includes 14,811 total observations.

ranges from $700 \mathrm{lb}$. to $1,700 \mathrm{lb}$. Complete summary statistics are included in Table 1.

In the AMS reports, prices from a set of lots are aggregated into homogenous groups with similar age, weight, and months bred classifications. Thus, the data reported are aggregate data and do not reflect individual lots sold. Figure 1 presents an example of how reporters aggregate bred cows into categories with similar characteristics. Because of aggregation, the variables price, age, months bred, and weight are reported as ranges. The midpoint of each range is used as the observation for each lot.

Age ranges from 2 to 10 years. AMS reporters also report prices for bred heifers. Heifers are coded as 1-year-olds, for comparison. In this context, age is a reference for the number of calves born. The variable age is expected to have a nonlinear impact on price. As bred cows age, they will receive discounts at an increasing rate because of the reduced useful life of the capital asset. Research on optimal cow size (Bir et al., 2016; Doye and Lalman, 2011) suggests that smaller cows are optimal. The argument is that a smaller cow eats less than a large cow and can wean a relatively heavier calf if bred to a larger bull. As months bred increases, the gestating cows are expected to receive a higher price.

Each bred cow lot is assigned a measure of quality reported in five categories: high, high-average, average, average-low, and low. The market reporter determines cow quality by visual inspection. The classifications highaverage and average-low are assigned when the quality of the lot is not uniform. Higher-quality cows are expected to receive premiums, whereas lower-quality 
KO_LS155

Wed Mar 25, 2015

Receipts This Week: 6,739

Last Week: 11,774

Last Year: 8,761

A total of 158 cows and bulls sold with 60 percent going to packers.

Replacement Cows: Pre-tested for pregnancy, and age.

Medium and Large 1-2:

Age weight

Heifers $\quad 850$

Heifers $\quad 850$

2-5 yr old 1000-1300

5-6 yr old $975-1000$

6-7 yr old 1375-1525

7-10yr old 1050-1450

Months Bred

5-7 months

5-7 months

6-7 months

7 months

7 months

7-10yr old 1050-1250

4-6 months

5-6 months

Quality
avg black
avg quality
hi black
avg black
hi black
avg black
avg quality

Price

1625.00-1950.00

1750.00-1760.00

2325.00-2475.00

1800.00-1950.00

2325.00

1550.00-1925.00

1425.00-1900.00

Figure 1. Example Bred Cow Auction Report (source: U.S. Department of Agriculture, Agricultural Marketing Service)

cows are expected to be discounted. In addition to quality, bred cows are given a black or nonblack hide color classification. Black cows are expected to receive a higher price than nonblack cows.

Supplementary data include daily Chicago Mercantile Exchange feeder cattle and corn futures prices, obtained from the LMIC, to represent price expectations. Feeder cattle futures prices serve as a proxy for expected output prices, and corn futures prices measure expected input costs (Schroeder et al., 1988). There is expected to be a negative impact on price, as corn futures prices increase. Likewise, it is expected that there will be a positive effect on price as feeder cattle futures prices increase. These expectations are consistent with those of related studies (Bailey, Peterson, and Brorsen, 1991; Buccola, 1980; Schroeder et al., 1988; Turner, Dykes, and McKissick, 1991; Zimmerman et al., 2012).

\section{Bred Cow Model}

In Lancaster's (1966) seminal article, “A New Approach to Consumer Theory,” he argues that utility is derived not from the good being consumed, but rather from the characteristics that a good possesses. Later, Ladd and Martin (1976) took a product characteristic approach to farm production inputs. Ladd and Martin's (1976) input characteristic model (ICM) illustrates how the value of production inputs is equal to the sum of the value of the input characteristics. Ladd and Martin (1976) provide a theoretical framework for researchers to model livestock price determinants. A similar approach to Ladd and Martin is 
used here, specifically those extensions of ICM found in the livestock marketing literature.

Bred cow prices reflect supply and demand conditions in a given market at a point in time. For any given auction, supply is fixed in the short run and prices are determined by the demand for a set of bred cow characteristics. From Ladd and Martin (1976), the demand for an input is influenced by the input's characteristics, which allows price to be a function of physical characteristics. Through previous extensions of ICM (Bailey, Brorsen, and Thomsen, 1995; Dhuyvetter et al., 1996; Mintert et al., 1990; Parcell, Schroeder, and Hiner, 1995; Schroeder et al., 1988; Williams et al., 2012; Zimmerman et al., 2012), the price of a lot of bred cows can be specified as a function of physical characteristics $(C)$ and market forces $(M)$, formulated as follows:

$$
\text { Price }_{i t}=\sum_{k} V_{i k t} C_{i k t}+\sum_{b} R_{b t} M_{b t},
$$

where $i$ refers to a lot of bred cows sold in time period $t, V$ is the marginal value of bred cow trait $k$, and $R$ is the marginal effect of market factor $b$ (Schroeder et al., 1988). Factors included as market forces are price expectations, both input costs and output price expectations, sale location, and the week of sale. Equation (1) states that the price per head equals the sum of the marginal implicit values of each lot's characteristics times the yield of each characteristic (Ladd and Martin, 1976) and the price effect of each market force (Mintert et al., 1990; Schroeder et al., 1988).

Equation (1) is estimated to get the marginal value of bred cow characteristics and market factors. Average price per head per lot is the dependent variable in equation (1). A log-log functional form is specified for all price variables. To account for location effects, common in the livestock literature, dummy variables are assigned to the seven reporting auctions. Price seasonality is accounted for by specifying a trigonometric functional form across weeks of the year. Previous research has included random effects for sale location and uses a mixed model approach to estimate the hedonic model (Williams et al., 2012). Similarly, a random effect for each sale location/week combination is incorporated into equation (1). All other characteristics and market forces are treated as fixed effects. The empirical model estimated is

$$
\begin{aligned}
\ln \left(\text { Price }_{i}\right)= & \beta_{0}+\sum_{j=1}^{9} \beta_{1 j} \text { Age }_{i j}+\sum_{j=1}^{8} \beta_{2 j} \text { MBred }_{i j}+\sum_{j=1}^{9} \beta_{3 j} \text { Wt }_{i j} \\
& +\sum_{j=1}^{4} \beta_{4 j} \text { Qlty }_{i j}+\beta_{5} \text { Black }_{i}+\sum_{j=1}^{6} \beta_{6 j} \text { Loc }_{i j}+\beta_{7} \ln \left(\text { Corn }_{i}\right) \\
& +\beta_{8} \ln \left(\text { Feeder }_{i}\right)+\sum_{(j=1)}^{2}\left[\beta_{10 j} \cos \left(\frac{(2 \pi t(i))}{26 j}\right)+\beta_{11_{j}} \sin \left(\frac{(2 \pi t(i))}{26 j}\right)\right] \\
& +\mu_{s_{(i)}}+\varepsilon_{i},
\end{aligned}
$$


Table 2. Description of Variables Used in the Bred Cow Hedonic Model

\begin{tabular}{|c|c|}
\hline Variable & Definition \\
\hline Price $_{i}$ & The average price per head of bred cow category $i(\$ /$ head $)$ \\
\hline$A g e_{i j}$ & $\begin{array}{l}\text { Ten binary variables }(0 \text { or } 1) \text { for age in years } \\
\quad j=1, \ldots, 10 ; \text { base }=3\end{array}$ \\
\hline MBred $_{i j}$ & $\begin{array}{l}\text { Nine binary variables }(0 \text { or } 1) \text { for months bred } \\
\quad j=1, \ldots, 9 ; \text { base }=6\end{array}$ \\
\hline$W t_{i j}$ & $\begin{array}{l}\text { Ten binary variables }(0 \text { or } 1 \text { ) for weight } \\
\text { Weight is included as hundred pound ranges } \\
\begin{array}{l}j=1, \ldots, 10 ; 1=700-800,2=801-900,3=901-1,000,4=1,001-1,100 \\
5=1,101-1,200,6=1,201-1,300,7=1,301-1,400,8=1,401-1,500 \\
9=1,501-1,600 \\
10=1,601-1,700 ; \text { base }=901-1,000\end{array}\end{array}$ \\
\hline Qlty $_{i j}$ & $\begin{array}{l}\text { Binary variables }(0 \text { or } 1) \text { for cow quality } \\
\quad j=1, \ldots, 5 ; 1=\text { low, } 2=\text { low-average, } 3=\text { average, } 4=\text { average-high, } \\
5=\text { high; base }=\text { average }\end{array}$ \\
\hline Black $_{i}$ & $\begin{array}{l}\text { Hide color of each lot } \\
\qquad 0=\text { nonblack, } 1=\text { black }\end{array}$ \\
\hline $\operatorname{Loc}_{i j}$ & $\begin{array}{l}\text { Binary variables }(0 \text { or } 1) \text { for sale location } \\
\quad j=1, \ldots, 7 ; 1=\text { Ada, } 2=\text { Apache, } 3=\text { El Reno, } 4=\text { Oklahoma City, } 5=\text { Tulsa, } \\
6=\text { McAlester, } 7=\text { Woodward } \text { base }=\text { Oklahoma City }\end{array}$ \\
\hline $\operatorname{Corn}_{i}{ }^{\mathrm{a}}$ & $\begin{array}{l}\text { The closing corn futures price of the nearby contract for the trading day } \\
\text { corresponding to the auction date }(\$ / \text { bushel). }\end{array}$ \\
\hline Feeder $_{i}{ }^{\mathrm{a}}$ & $\begin{array}{l}\text { The closing feeder cattle futures price of the nearby contract for the trading day } \\
\text { corresponding to the auction date }(\$ / \mathrm{cwt} .) \text {. }\end{array}$ \\
\hline
\end{tabular}

a When no trading occurred on the day of the sale, the previous day's closing feeder cattle and corn futures prices of the nearby contracts are used to reflect market conditions.

where $i$ is the observation number of reported categories of lots $(i=1,2, \ldots$, $14,811) ; t(i)$ denotes the sale week of observation $i$; Price $_{i}$ is the reported average price per head; $A g e_{i j}$ represents dummy variables for age in years (3 years is reference); MBred $_{i j}$ represents dummy variables for months bred (6 months bred is reference); $W t_{i j}$ represents dummy variables for cow weight in hundred pound ranges (901-1,000 lb. is reference weight); Qlty lij $_{\text {represents dummy variables }}$ for cow quality (average quality is reference); Black $k_{i}$ equals 1 if hide color is black and 0 if hide color is nonblack; $L o c_{i j}$ represents dummy variables for sale location (Oklahoma City is reference); Corn $n_{i}$ is the closing corn futures price per bushel of the nearby contract for the trading day corresponding to the auction date; Feeder $i$ is the closing feeder cattle futures price per hundredweight (cwt.) of the nearby contract for the trading day corresponding to the auction date; $26 j$ denotes the sinusoidal period; $\mu_{s(i)}$ is the random effect for each sale location and date combination; $s(i)$ is the location/date combination for the $i$ th observation; and $\varepsilon_{i}$ is the random error term for each observation. Further description of variables is provided in Table 2 . 
Previous research has modeled age and weight as linear terms, and often the significance of a quadratic term is tested (Faminow and Gum, 1986; Dhuyvetter et al., 1996; Parcell, Schroeder, and Hiner, 1995; Schroeder et al., 1988; Williams et al., 2012). Rather than imposing a restrictive functional form, age and weight categories are included as indicator variables. Age was divided into 10 separate binary variables. Because the midpoint of each age range was used as the observation, there were 20 values that age could take. Age was rounded up to the nearest year. For example, an observation with a midpoint of 1.5 was rounded up to be 2 years. Similarly, 10 weight classes were included and assigned separate binary variables. Months bred ranges from 1 to 9 months bred. The average months bred is used as the observation for each lot; this created observations that were in 2-week increments. Months bred was rounded up to the nearest month, so that 5 months represents midpoints of 4.5 to 5 months. Nine separate binary variables were created for months bred.

The hedonic model is estimated with maximum likelihood using the MIXED procedure of SAS 9.4 (SAS Institute Inc., 2008). To estimate equation (2), an arbitrary reference lot of bred cows is selected. Three years of age is selected as the base age, and 901 to 1,000 lb. is chosen as the base weight class. Six months bred is selected as the base. Average quality is selected as the base quality. Oklahoma City is assigned as the base sale location. All estimated coefficients reflect price effects relative to the base lot.

One estimation concern is heteroskedasticity, particularly because of aggregation (Richter and Brorsen, 2006). Results from a likelihood ratio test indicate the presence of heteroskedasticity arising from the variables sale volume, average weight, average age, and average months bred. Heteroskedasticity is corrected for by specifying multiplicative heteroskedasticity (Judge et al., 1985) in the variance equation for the four variables as follows:

$$
\begin{aligned}
E\left[e_{i}^{2}\right]=\sigma_{i}^{2}= & \exp \left[\alpha_{1}+\alpha_{2} \text { CatVol }_{i}+\alpha_{3} \text { AvgAge }_{i}\right. \\
& \left.+\alpha_{4} A v g W t_{i}+\alpha_{5} \text { AvgMBred }_{i}\right]
\end{aligned}
$$

where $A v g A g e_{i}, A v g W t_{i}$, and AvgMbred ${ }_{i}$ are the midpoints of each age, weight, and months bred range. $\mathrm{CatVol}_{i}$ is the number of cows per category. As volume per category increases, a greater number of bred cows are aggregated into categories with similar age, weight, and months bred characteristics. Thus, as aggregation occurs over a greater number of cows, the variance of the error term is smaller.

\section{Results}

Parameter estimates for the bred cow hedonic model are included in Table 3. With such a large sample, most characteristics are significant at the 0.01 level. All coefficients have the expected sign. Estimates reveal significant price variation 
Table 3. Hedonic Model Parameter Estimates of the Logarithm of Bred Cow Prices

\begin{tabular}{|c|c|c|}
\hline Variable & Estimate & $P$ Value \\
\hline Intercept & 1.5222 & $<0.0001$ \\
\hline \multicolumn{3}{|l|}{ Age $($ base $=3$ ) } \\
\hline 1 & 0.0338 & $<0.0001$ \\
\hline 2 & 0.0134 & 0.0032 \\
\hline 4 & 0.0028 & 0.3793 \\
\hline 5 & -0.0097 & 0.0017 \\
\hline 6 & -0.0344 & $<0.0001$ \\
\hline 7 & -0.0712 & $<0.0001$ \\
\hline 8 & -0.1158 & $<0.0001$ \\
\hline 9 & -0.1718 & $<0.0001$ \\
\hline 10 & -0.2363 & $<0.0001$ \\
\hline \multicolumn{3}{|c|}{$W t($ base $=901-1,000)$} \\
\hline $700-800$ & -0.1163 & $<0.0001$ \\
\hline $801-900$ & -0.0503 & $<0.0001$ \\
\hline $1,001-1,100$ & 0.0340 & $<0.0001$ \\
\hline $1,101-1,200$ & 0.0651 & $<0.0001$ \\
\hline $1,201-1,300$ & 0.0879 & $<0.0001$ \\
\hline $1,301-1,400$ & 0.1047 & $<0.0001$ \\
\hline $1,401-1,500$ & 0.1321 & $<0.0001$ \\
\hline $1,501-1,600$ & 0.1198 & $<0.0001$ \\
\hline $1,601-1,700$ & 0.1361 & 0.0012 \\
\hline \multicolumn{3}{|c|}{ MBred $($ base $=6)$} \\
\hline 1 & -0.1210 & 0.0459 \\
\hline 2 & -0.0773 & $<0.0001$ \\
\hline 3 & -0.0671 & $<0.0001$ \\
\hline 4 & -0.0416 & $<0.0001$ \\
\hline 5 & -0.0164 & $<0.0001$ \\
\hline 7 & 0.0193 & $<0.0001$ \\
\hline 8 & 0.0360 & $<0.0001$ \\
\hline 9 & -0.0003 & 0.9965 \\
\hline Black & 0.0663 & $<0.0001$ \\
\hline \multicolumn{3}{|c|}{ Qlty (base = average) } \\
\hline High & 0.1381 & $<0.0001$ \\
\hline Average-high & 0.0832 & $<0.0001$ \\
\hline Low-average & -0.0635 & $<0.0001$ \\
\hline Low & -0.1483 & $<0.0001$ \\
\hline \multicolumn{3}{|c|}{ Loc (base = Oklahoma City) } \\
\hline Ada & 0.0341 & $<0.0001$ \\
\hline Apache & 0.0438 & $<0.0001$ \\
\hline El Reno & 0.0201 & $<0.0001$ \\
\hline McAlester & 0.0205 & $<0.0001$ \\
\hline Tulsa & 0.0643 & $<0.0001$ \\
\hline Woodward & 0.0645 & $<0.0001$ \\
\hline $\operatorname{Cos} 26$ & -0.0149 & $<0.0001$ \\
\hline $\operatorname{Sin} 26$ & 0.0162 & $<0.0001$ \\
\hline $\operatorname{Cos} 52$ & 0.0248 & $<0.0001$ \\
\hline $\operatorname{Sin} 52$ & 0.0519 & $<0.0001$ \\
\hline
\end{tabular}


Table 3. Continued

\begin{tabular}{lcr}
\hline \hline Variable & Estimate & $P$ Value \\
\hline Feeder & 1.1077 & $<0.0001$ \\
Corn & -0.0876 & $<0.0001$ \\
Variance of error term & 0.0244 & \\
Random effect variance & 0.0051 & \\
-2 Log likelihood & $-28,960.60$ & \\
\hline \hline
\end{tabular}

${ }^{\text {a }}$ The random effect differs for every location and sale combination.

regionally and seasonally. Estimates denote percent premiums and discounts for all binary variables. Estimates for futures prices denote price elasticities. The following sections provide a discussion of each variable included in the bred cow pricing model.

\subsection{Effect of Cow Age}

Age has a significant impact on the price received for bred cows with the exception of no significant difference between 4-year-old and 3-year-old bred cows. Bred heifers, coded as 1-year-olds, bring the greatest premiums; their respective price is $3.44 \%$ higher than 3 -year-olds. Ten-year-old bred cows receive a price that is $21.05 \%$ below the price of 3 -year-olds. Eight- and 9-year-olds bring discounts of $10.93 \%$ and $15.79 \%$, respectively.

The magnitude of the effect for first-calf heifers requires some explanation. It was hypothesized that 2- and 3-year-old bred cow lots would bring the greatest premiums. First-calf heifers are more likely to have calving problems, especially those from a sale barn that may not be bred to a bull selected for calving ease. First-calf heifers are less likely to rebreed and often wean a lighter calf. However, the negatives are overshadowed by the longer useful life of a younger bred cow, which results in the high estimated premium.

Producers market both young replacements and older cull cows as bred. Buyers assign discounts at an increasing rate as cows age (Figure 2). Producers considering marketing older cows as bred should acknowledge the heavy discounts assigned as age increases. In some instances, it may be more beneficial for producers to market older cows as open rather than bred when slaughter value of the cows dominates reproductive value. As noted by Mintert et al. (1990), the intentions of the buyers are not known. However, the heavy discounts for age may be a result of cattle buyers purchasing cows for packing facilities.

\subsection{Effect of Cow Weight}

Weight has a positive but diminishing impact on price (Figure 3). Cows weighing between 700 and $800 \mathrm{lb}$. receive a discount of $10.98 \%$. Cows weighing between 1,601 and $1,700 \mathrm{lb}$. receive the greatest premium of $14.58 \%$. In recent years, 


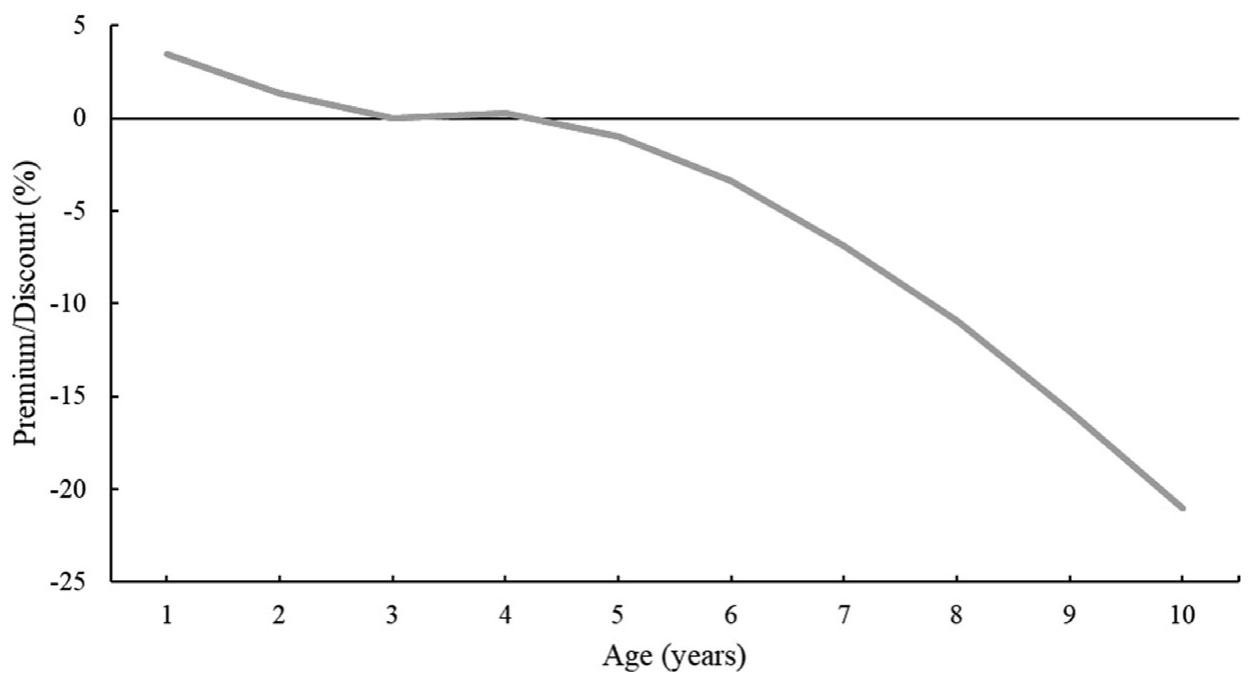

Figure 2. Effect of Cow Age on the Logarithm of Bred Cow Prices (base age 3 years)

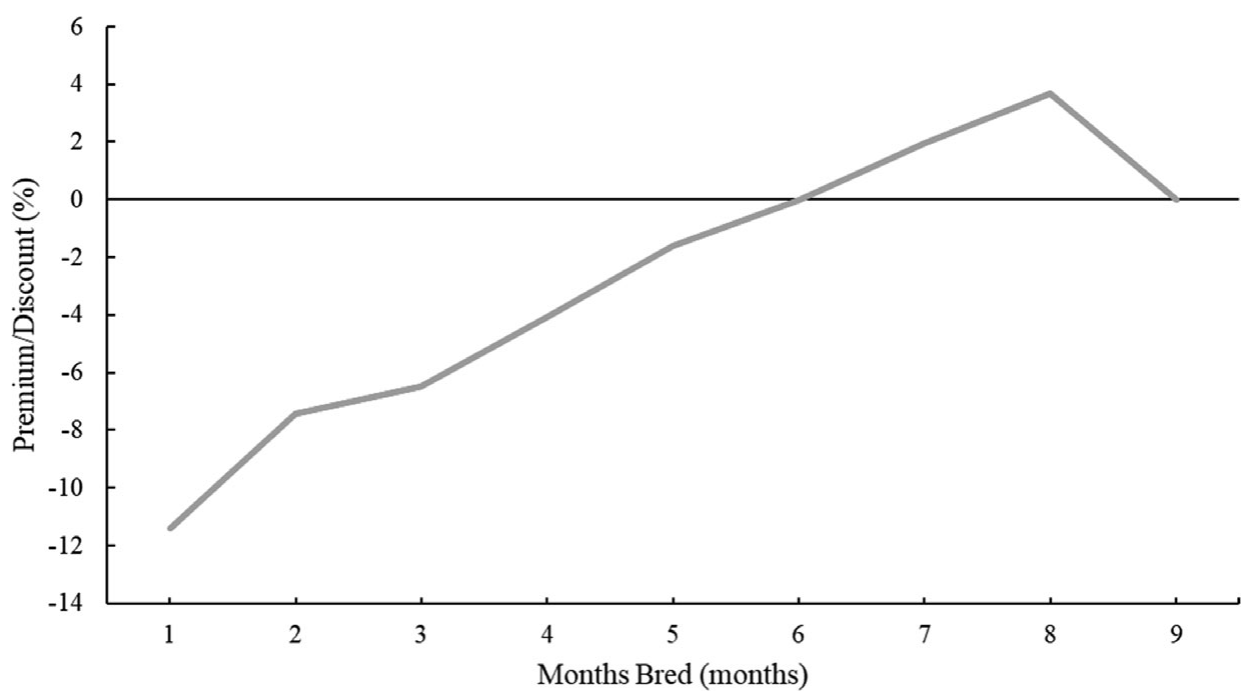

Figure 3. Effect of Months Bred on the Logarithm of Bred Cow Prices (base months bred is 6 months)

there has been a lot of discussion in the academic literature and popular press about optimal cow size and to some extent moderating the weight of the commercial beef cow (Doye and Lalman, 2011; Russell and Feuz, 2015; Schmid, 2013; Wareham, 2013). Using two pasture scenarios, Doye and Lalman (2011) found that moderate-sized cows $(1,000 \mathrm{lb}$.) were more profitable, in both cases, 
Table 4. Means of Logarithmic Bred Cow Prices for Seven Oklahoma Auctions by Weight Class, January 2000-May 2015

\begin{tabular}{lc}
\hline \hline Variable & Estimate $^{\mathrm{a}}$ \\
\hline Wt $(100 \mathrm{lb})$. & $6.56 \mathrm{a}$ \\
$700-800$ & $6.62 \mathrm{~b}$ \\
$801-900$ & $6.68 \mathrm{c}$ \\
$901-1,000$ & $6.71 \mathrm{~d}$ \\
$1,001-1,100$ & $6.74 \mathrm{e}$ \\
$1,101-1,200$ & $6.76 \mathrm{f}$ \\
$1,201-1,300$ & $6.78 \mathrm{~g}$ \\
$1,301-1,400$ & $6.81 \mathrm{~h}$ \\
$1,401-1,500$ & $6.79 \mathrm{ghi}$ \\
$1,501-1,600$ & $6.81 \mathrm{efghi}$ \\
$1,601-1,700$ & $6.05 \mathrm{level} \mathrm{by} \mathrm{diferch}$ \\
\hline \hline
\end{tabular}

${ }^{a}$ Means followed by the same letter are not significantly different at the $P \leq 0.05$ level by differences in least squares means.

Note: Wt includes 10 binary variables for each hundred pound bred cow weight class.

compared with big cows (1,400 lb.). Although their results varied depending on assumptions, Bir et al. (2016) found that the lightest-weight cows they considered were most often the optimal cow size. Research has identified smaller cows as optimal, but we find buyers place the greatest value on heavier cows. Although the cows are marketed as bred, some of them could be purchased for slaughter, in which case the extra weight would be valuable.

The small marginal change in the value of weight at heavier weight classes brings to question the significance of the three heaviest weight classes relative to one another. We estimate least squares means and test for differences in least squares means to determine if the three heaviest weight classes do, in fact, receive significantly different prices. Table 4 results show that there is no significant difference in mean prices for the three weight classes of interest, but this is at least partly because of a smaller number of observations in the two largest categories. Further, it is important to note that although producers receive a significant premium for heavier cows, the price per pound received for heavier cows is less than that of lighter cows. For example, using least squares means from Table 4, cows weighing between 901 and 1,000 lb. have a mean price of $\$ 0.84 / \mathrm{lb}$., whereas cows weighing between 1,401 and $1,500 \mathrm{lb}$. have a mean price of $\$ 0.63 / \mathrm{lb}$.

\subsection{Effect of Months Bred}

Months bred has the expected impact on price. Early and midgestating cows bring discounts, whereas late-gestating cows bring premiums. The discounts assigned to early and midgestating cows range from $11.40 \%$ for 1 -month bred cows to $1.62 \%$ for 5 -month bred cows. Buyers pay the highest premiums 
$(3.66 \%)$ for 8 -month bred cows. There is less risk of losing a calf and lower production costs prior to the calf's birth, and revenue is received more quickly when producers purchase late-gestating cows. Nine-month bred cows do not receive a price significantly different from 6 -month bred cows, but that may be partly the result of having few cows that are classified as being bred 9 months.

\subsection{Effect of Hide Color and Cow Quality}

Previous research has indicated that producers use hide color rather than breed to distinguish between classes of cattle (Bulut and Lawrence, 2007). Williams et al. (2012) find all other hide color classifications receiving discounts relative to black-hided calves. Bulut and Lawrence (2007) report a premium of \$3.34/cwt. for black-hide relative to nonblack feeder cattle. Similarly, Leupp et al. (2009) estimate a premium of $\$ 3.48 /$ cwt. for black calves sold in the fall. The only hide color reported for bred cows in AMS reports is black. As expected, black cows bring a premium of $6.86 \%$ relative to nonblack cows, which equates to a $\$ 5.70 /$ cwt. premium above the average price. The estimate for hide color is larger for bred cows than those estimates found in the feeder cattle hedonic literature (Bulut and Lawrence, 2007; Leupp et al., 2009; Williams et al., 2012).

Cow quality has breeding, calving, and health implications. Producers purchasing bred cows pay significant premiums for high and high-average quality cows. High and high-average quality bred cows garner premiums of $14.81 \%$ and $8.67 \%$, respectively. Heavy discounts are assigned to cows perceived as low quality; the respective discount for low-quality cows is $13.78 \%$. Lower quality may be a function of factors that cannot be changed (e.g., genetics) but may also reflect management of the cows (e.g., cows that are too thin).

\subsection{Effects of Location and Seasonality}

Results show significant spatial and seasonal bred cow price differences. Bred cows sold in all other locations receive significant premiums ranging from $2.03 \%$ at El Reno to $6.67 \%$ at Woodward relative to Oklahoma City. The premium estimates may reflect the cost of transporting cows from Oklahoma City to the more rural areas of the state where the majority of cow-calf operations are located. Buyers go to markets that are in close proximity to their ranches to invest in breeding animals.

To illustrate estimated price seasonality, the combined impact of the four estimated sine and cosine terms are plotted for a 52-week year (Figure 4). Buyers place the greatest value on cows sold in February and March. Prices are lowest in the summer and fall months, which is when producers are more likely to cull their herds. In addition, prices may be higher in late winter and spring as producers want to purchase cows in anticipation of summer grass pasture. 


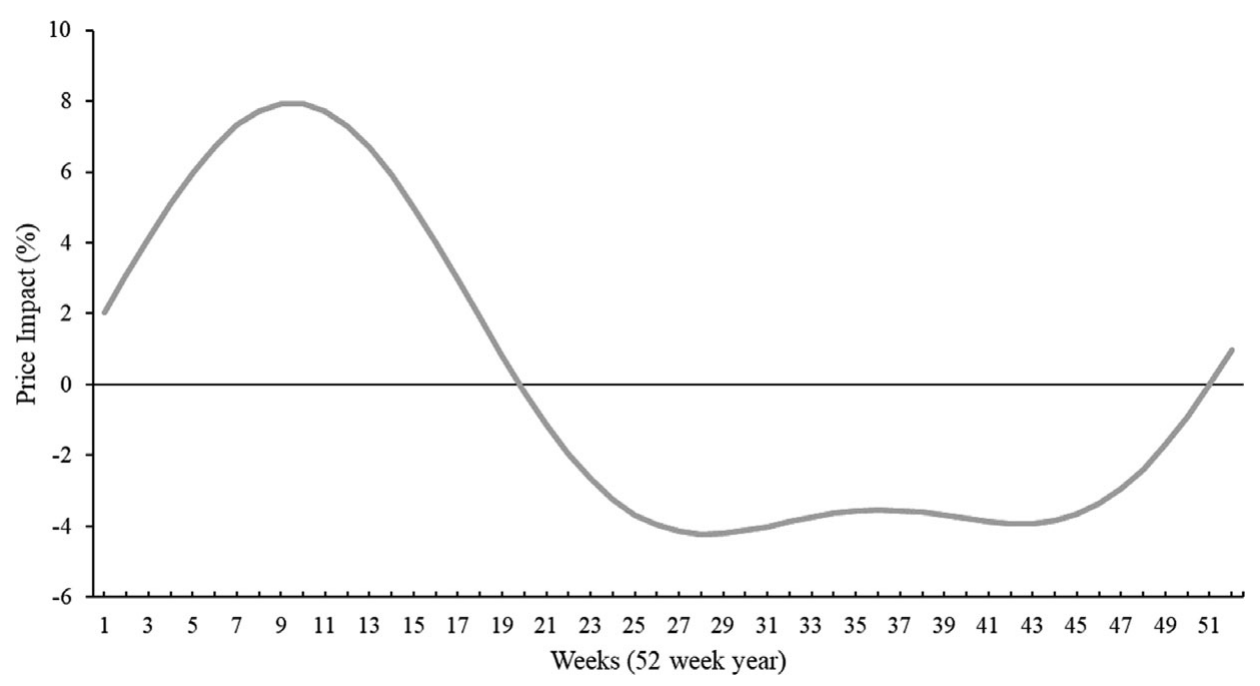

Figure 4. Seasonality of Logarithmic Bred Cow Prices for Seven Oklahoma Auctions

\section{Conclusions}

This research estimated hedonic prices of bred cow characteristics. Physical characteristics and market factors contribute significantly to the total value of a bred cow. Weight has a nonlinear impact on price, with cows weighing more than 1,000 lb. bringing premiums; cows weighing between 1,601 and 1,700 lb. receive the greatest premium of $14.58 \%$. Retaining cows and marketing them during the third trimester can significantly increase value. Cows graded as low quality receive a substantial discount. Similar to previous studies, this research includes feeder cattle and corn futures prices to serve as proxy variables for market expectations (Schroeder et al., 1988; Zimmerman et al., 2012). Results are consistent with previous research in that increases in corn futures prices have an adverse impact on bred cow prices, whereas increases in feeder cattle futures prices have a positive impact.

Animal and lot level auction data have been the most common source used in livestock hedonic studies (e.g., Avent, Ward, and Lalman, 2004; Bailey, Peterson, and Brorsen, 1991; Schroeder et al., 1988; Schulz, Dhuyvetter, and Doran, 2015). Another contribution of this research is the use of aggregate auction data. Although USDA-AMS reports prices and characteristics of all classes of cattle, no previous research has utilized these publicly available reports to assess the market value of livestock characteristics.

In an industry where marketing strategies are increasingly more important, the information presented here may allow producers to improve their cow-marketing practices. Future research should consider whether buyers may want to reduce 
the premiums they pay for larger cows. The results of this research could benefit both buyers and sellers of bred cows. Sellers receive significant premiums for marketing bred cows with traits that buyers deem valuable.

\section{References}

Amadou, Z. "Value Enhancement Marketing Strategies for Cull Beef Cows." Ph.D. dissertation, Oklahoma State University, Stillwater, 2012.

Amadou, Z., K.C. Raper, J.T. Biermacher, B. Cook, and C.E. Ward. "Net Returns from Feeding Cull Beef Cows: The Influence of Initial Body Condition Score.” Journal of Agricultural and Applied Economics 46,1(2014):139-55.

Avent, R.K., C.E. Ward, and D.L. Lalman. "Market Valuation of Preconditioning Feeder Calves." Journal of Agricultural and Applied Economics 36,1(2004):173-83.

Bailey, D.V., B.W. Brorsen, and M.R. Thomsen. "Identifying Buyer Market Areas and the Impact of Buyer Concentration in Feeder Cattle Markets Using Mapping and Spatial Statistics." American Journal of Agricultural Economics 77,2(1995):309-18.

Bailey, D.V., M.C. Peterson, and B.W. Brorsen. "A Comparison of Video Cattle Auction and Regional Market Prices.” American Journal of Agricultural Economics 73,2(1991):46575.

Bir, C., E.A. DeVuyst, M. Rolf, and D. Lalman. "Optimal Beef Cow Weights in the U.S. Southern Plains.” Unpublished working paper, Oklahoma State University, 2016.

Blank, S.C., T.L. Saitone, and R.J. Sexton. "Calf and Yearling Prices in the Western United States: Spatial, Quality, and Temporal Factors in Satellite Video Auctions.” Journal of Agricultural and Resource Economics 41,3(2016):458-80.

Buccola, S.T. "An Approach to the Analysis of Feeder Cattle Price Differentials." American Journal of Agricultural Economics 62,3(1980):574-80.

Bulut, H., and J.D. Lawrence. "The Value of Third-Party Certification of Preconditioning Claims at Iowa Feeder Cattle Auctions." Journal of Agricultural and Applied Economics 39,3(2007):625-40

Coatney, K.T., D.J. Menkhaus, and J.D. Schmitz. "Feeder Cattle Price Determinants: An Hedonic System of Equations Approach." Review of Agricultural Economics 18,2(1996):193-211.

Dhuyvetter, K.C., T.C. Schroeder, D.D. Simms, R.P. Bolze Jr., and J. Geske. “Determinants of Purebred Beef Bull Price Differentials.” Journal of Agricultural and Resource Economics 21,2(1996):396-410.

Doye, D., and D. Lalman. “Moderate versus Big Cows: Do Big Cows Carry Their Weight on the Ranch?" Paper presented at the Southern Agricultural Economics Association Annual Meeting, Corpus Christi, TX, February 5-8, 2011.

Faminow, M.D., and R.L. Gum. "Feeder Cattle Price Differentials in Arizona Auction Markets." Western Journal of Agricultural Economics 11,2(1986):156-63.

Grunfeld, Y., and Z. Griliches. "Is Aggregation Necessarily Bad?" Review of Economics and Statistics 42,1(1960):1-13.

Gupta, K.L. “Aggregation Bias in Linear Economic Models.” International Economic Review 12,2(1971):293-305.

Judge, G.G., W.E. Griffiths, R.C. Hill, H. Kutkepohl, and T. Lee. The Theory and Practice of Econometrics. 2nd ed. New York: John Wiley and Sons, 1985.

Ladd, G.W., and M.B. Martin. "Prices and Demands for Input Characteristics." American Journal of Agricultural Economics 58,1(1976):21-30. 
Lancaster, K.J. “A New Approach to Consumer Theory.” Journal of Political Economy 74,2(1966):132-57.

Lawrence, J.D. Profiting from the Cattle Cycle: Alternative Cow Herd Investment Strategies. Ames: Iowa State University, Beef Research Report, 2002.

Lee, K.C., M.H. Pesaran, and R.G. Pierse. "Testing for Aggregation Bias in Linear Models." Economic Journal 100,400(1990):137-50.

Leupp, J.L., G.P. Lardy, R. Daly, C.L. Wright, and J.A. Paterson. "Factors Influencing Price of North Dakota, South Dakota and Montana Feeder Calves." Beef Cattle and Range Research Report. Fargo: North Dakota State University, 2009, pp. 46-49.

Mallory, S., E.A. DeVuyst, K.C. Raper, D. Peel, and G. Mourer. "Effect of Location Variables on Feeder Calf Basis at Oklahoma Auctions." Journal of Agricultural and Resource Economics 41,3(2016):393-405.

Marsh, J.M. "Monthly Price Premiums and Discounts between Steer Calves and Yearlings." American Journal of Agricultural Economics 67,2(1985):307-14.

Mintert, J., J. Blair, T. Schroeder, and F. Brazle. "Analysis of Factors Affecting Cow Auction Price Differentials." Southern Journal of Agricultural Economics 22,2(1990): 23-30.

Parcell, J.L., T.C. Schroeder, and F.D. Hiner. "Determinants of Cow-Calf Pair Prices.” Journal of Agricultural and Resource Economics 20,2(1995):328-40.

Peel, D.S., and D. Doye. Cull Cow Grazing and Marketing Opportunities. Stillwater: Oklahoma Cooperative Extension Service, Oklahoma State University, Fact Sheet AGEC-613, 2008. Internet site: http://pods.dasnr.okstate.edu/docushare/dsweb/Get/ Document-8252/AGEC-613web.pdf (Accessed August 2016).

Pesaran, M.H., R.G. Pierse, and M.S. Kumar. "Econometric Analysis of Aggregation in the Context of Linear Prediction Models." Econometrica 57,4(1989):861-88.

Richter, F.G.-C., and B.W. Brorsen. "Aggregate versus Disaggregate Data in Measuring School Quality." Journal of Productivity Analysis 25,3(2006):279-89.

Russell, J., and D. Feuz. "The Optimal Cow Size for Intermountain Cow-Calf Operations.” Fact Sheet No. 3.767, Fort Collins: Colorado State University Extension Services, 2015. Internet site: http://extension.colostate.edu/topic-areas/agriculture/the-optimal-cowsize-for-intermountain-cow-calf-operations-3-767/ (Accessed July 2016).

Sasaki, K. "An Empirical Analysis of Linear Aggregation Problems: The Case of Investment Behavior in Japanese Firms.” Journal of Econometrics 7,3(1978):313-31.

SAS Institute Inc. SAS/STAT (R) 9.2 Users Guide. Cary, NC: SAS Institute Inc., 2008.

Schmid, K. "Bigger Is Not Always Better: Finding the Right Sized Cow." BeefResearch, November 22, 2013. Internet site: http://www.beefresearch.ca/blog/finding-the-rightsized-cow/ (Accessed July 2016).

Schroeder, T., J. Mintert, F. Brazle, and O. Grunewald. "Factors Affecting Feeder Cattle Price Differentials." Western Journal of Agricultural Economics 13,1(1988):71-81.

Schulz, L., K.C. Dhuyvetter, and B.E. Doran. "Factors Affecting Preconditioned Calf Price Premiums: Does Potential Buyer Competition and Seller Reputation Matter?" Journal of Agricultural and Resource Economics 40,2(2015):220-41.

Schulz, L., and P. Gunn. "Raising versus Buying Heifers for Beef Cow Replacement." File B1-73, Ames: Iowa State University Extension and Outreach, Iowa State University, 2014. Internet site: https://www.extension.iastate.edu/agdm/livestock/html/b1-73.html (Accessed April 2016).

Shumway, C.R., and G.C. Davis. "Does Consistent Aggregation Really Matter?” Australian Journal of Agricultural and Resource Economics 45,2(2001):161-94. 
Theil, H. Linear Aggregation of Economic Relations. Amsterdam: North-Holland, 1954.

Trapp, J.N. "Investment and Disinvestment Principles with Nonconstant Prices and Varying Firm Size Applied to Beef-Breeding Herds." American Journal of Agricultural Economics 68,3(1986):691-703.

Turner, S.C., N.S. Dykes, and J. McKissick. "Feeder Cattle Price Differentials in Georgia Teleauctions." Southern Journal of Agricultural Economics 23,2(1991):75-84.

Vestal, M.K., J.L. Lusk, E.A. DeVuyst, and J.R. Kropp. "The Value of Genetic Information to Livestock Buyers: A Combined Revealed, Stated Preference Approach.” Agricultural Economics 44,3(2013):337-47.

Wareham, J. "What Is the Ideal Cow Size?" Drovers, August 13, 2013. Internet site: http: //www.cattlenetwork.com/drovers/columns/What-is-the-ideal-cow-size-219406021. html (Accessed July 2016).

Williams, G.S., K.C. Raper, E.A. DeVuyst, D. Peel, and D. McKinney. "Determinants of Price Differentials in Oklahoma Value-Added Feeder Cattle Auctions." Journal of Agricultural and Resource Economics 37,1(2012): 114-27.

Zimmerman, L.C., T.C. Schroeder, K.C. Dhuyvetter, K.C. Olson, G.L. Stokka, J.T. Seeger, and D.M. Grotelueschen. "The Effect of Value-Added Management on Calf Prices at Superior Livestock Auction Video Markets." Journal of Agricultural and Resource Economics 37,1(2012):128-43. 